\title{
Integration of sedimentology and ground-penetrating radar for high- resolution imaging of a carbonate platform
}

\author{
Stéphan J. Jorry ${ }^{1, *}$ and Grégory Bièvre ${ }^{2,3}$ \\ ${ }^{1}$ IFREMER, Géosciences Marines, BP 70, 29280 Plouzané Cedex, France \\ ${ }^{2}$ Laboratoire Régional d'Autun, Centre d'Études Techniques de l'Équipement de Lyon, BP 141, 71404 Autun \\ Cedex, France \\ 3 Laboratoire de Géophysique Interne et de Tectonophysique, UMR-CNRS 5559, Université Joseph Fourier, \\ BP53 38041 Grenoble cedex 9, France Associate Editor - Gregor Eberli \\ *: Corresponding author : Stéphan J. Jorry, email address : stephan.jorry@ifremer.fr
}

\begin{abstract}
:
Ground-penetrating radar has not been applied widely to the recognition of ancient carbonate platform geometries. This article reports the results of an integrated study performed on an Upper Jurassic outcrop from the south-east Paris basin, where coral bioherms laterally change into prograding depositional sequences. Ground-penetrating radar profiles illustrate the different bedding planes and major erosional unconformities visible at outcrop. A ground-penetrating radar profile conducted at the base of the cliff displays a palaeotopographic surface on which the outcropping bioherms settled. The excellent penetration depths of the ground-penetrating radar $(20 \mathrm{~m}$ with a monostatic $200 \mathrm{MHz}$ antenna) images the carbonate platform geometries, ranging between outcrop workscale (a few metres) and seismic scale (several hundreds of metres). This study supports recent evidence of icehouse conditions and induced sea-level fluctuations controlling the Upper Jurassic carbonate production.
\end{abstract}

Keywords : Carbonate platform ; coral bioherms ; ground-penetrating radar ; Late Jurassic ; Paris Basin 


\section{INTRODUCTION}

Ground-Penetrating Radar (GPR) is a non-invasive technique for detecting, locating and/or mapping shallow subsurface features. GPR has often been used for 2D and 3D characterization of clastic reservoirs (McMechan et al., 1998; Jol et al., 2003), glaciofluvial deposits (Beres \& Haeni, 1991; Beres et al., 1995, 1999) with applications to aquifer reservoir modeling (Asprion \& Aigner, 1999; Heinz \& Aigner, 2003; Huggenberger \& Regli, 2006), and to hydrostratigraphical characterization (Goutaland et al., 2008). Remarkably few studies have examined facies and geometries of carbonates: the characterization of a Middle Silurian bioclastic grainstone megashoal (Pratt \& Miall, 1993), the recognition of facies in Upper Jurassic limestones (Asprion \& Aigner, 1999, 2000; Dagallier et al., 2000), and the characterization of decimetre-scale to metre-scale sedimentary structures in a Pleistocene oolite shoal-barrier bar setting (Grasmueck \& Weger, 2002; Grasmueck et al., 2004) are some of the studies using GPR in carbonates. To our knowledge, only one study published by Asprion et al. (2009) integrates sedimentology and geophysics to characterize facies and geometry of a carbonate platform in order to interpret subsurface facies and geometry.

The deposition of the Upper Jurassic facies in the Tethys domain typically reflects the high-carbonate production occurring at the end of the Jurassic, when continental shelves were flooded during sea-level highstands (Leinfelder, 2001). In terms of sequence stratigraphy, Upper Jurassic first and second order sea-level changes were controlled by tectono-eustatism, the major cause probably being the expanse of mid-oceanic ridges during the breakup of Pangea (Leinfelder, 1993, 2001). Causes for third and higher order sea-level fluctuations remain unclear, and a strong controversy exists in the interpretation of the Upper Jurassic climate. Most of available $\delta^{18} \mathrm{O}$ data suggest the onset of a warming phase 
throughout the middle-late Oxfordian (Hoffman et al., 1991; Price \& Sellwood, 1997; Price \& Gröcke, 2002; Wiezbowski, 2002, 2004; Gröcke et al., 2003). Global biochemical models predict high $\mathrm{pCO}_{2}$ levels (Berner, 1994) and simulations of climate regimes using General Circulation Models do not rule out the seasonal formation of ice caps (Moore et al., 1992a, 1992b; Ross et al., 1992; Valdes \& Sellwood, 1992; Sellwood \& Valdes, 1997; Sellwood et al., 2000). However, based on sea surface palaeotemperature values calculated on oxygen isotopes of low-Mg calcitic and aragonitic shells from tropical sea water, Veizer et al., (2000) proposed an icehouse mode for the Late Jurassic. To explain the apparent contradiction with high $\mathrm{pCO}_{2}$ levels, the authors suggested that atmospheric carbon dioxide concentrations were not the principal driver of climate variability, at least for the Late Jurassic. This icehouse mode is confirmed by a recent work published by Dromart et al. (2003) evidencing that the Upper Jurassic climate is characterized by "... brief and global cooling affected sea surface temperatures at the Middle-Late Jurassic transition (around the Callovian-Oxfordian boundary) and was plausibly associated with the formation of subpolar continental ice". The magnitude of cooling was about 1 to $3^{\circ} \mathrm{C}$ for lower middle latitudes and resulted in an abrupt global-scale fall of sea level (Haq et al., 1988; Pittet \& Strasser, 1998; Pittet et al., 2000; Badenas et al., 2005).

This work presents an example of the application of GPR to imaging carbonate platforms. The sedimentological study aims to define the shape and the size of the sedimentary packages and their stacking patterns, and to map the carbonate sedimentary bodies and large-scale unconformities at outcrop and on GPR profiles. In a second step, radar facies are defined in order to interpret facies and geometry on an additional GPR survey realized on the subsurface, where no exposure is available. By combining outcrop information with 2D GPR surveys, this study gives rise to some discussions about the 
external parameters controlling the growth of Upper Jurassic bioherms and provides evidence that the Jurassic indeed was an icehouse world.

\section{GEOLOGICAL AND GEOPHYSICAL BACKGROUND}

\section{Jurassic bioherms in the Paris Basin}

During the Early Jurassic, bioherms were generally very rare in the Tethyan realm, but the important rise of sea level during the Middle Jurassic triggered their development on the northern Tethys shelf which turned into a carbonate-dominated province (Leinfelder, 2001). Only during Late Jurassic times were shelf areas flooded widely enough to define suitable carbonate ramp settings (Leinfelder, 2001). A large part of the European continent was covered with shallow epireic seas connecting different sedimentary basins (Paris, Dauphinois, and Aquitaine deep marine environments) (Fig. 1). In France, the shallow marine carbonate production was preferentially distributed around the Massif Central between $20^{\circ}$ and $30^{\circ}$ of latitude (Vogt \& Tucholke, 1986; Leinfelder, 1987; Ziegler, 1988; Leinfelder, 1989; Ellis et al., 1990).

In the Paris Basin, the upper Oxfordian bioherms from the southern margin are dominated by corals (Loreau \& Tintant, 1968). About 130 genera in the Upper Jurassic are described (Leinfelder et al., 1994; Bertling \& Insalaco, 1998). An important climatic change appears to have occurred during the middle to late Oxfordian transition, initiating major biohermal development in the Swiss Jura and in other regions of the northern shelf margin of the Tethys (Gygi, 1986; Gygi \& Persoz, 1986; Pittet, 1996; Pittet \& Strasser, 1998; Pittet et al., 2000; Cecca et al., 2001; Olivier et al., 2003, 2004). At the beginning of the late 
Oxfordian, abundant rainfall triggered terrigeneous sediment input resulting in the development of a more mixed siliciclastic/carbonate system (Olivier et al., 2004).

The study area is located in the south-east of the Paris Basin (Fig. 2A) and focuses on the Calcaire de Tonnerre Formation. Several studies describe upper Oxfordian bioherms on the southern margin of the Paris Basin known as the Chatel Censoir biostromes (Menot \& Rat, 1967; Menot, 1974, 1980; Insalaco, 1996; Chevalier et al., 2001). They occur between the top of the Transversarium Zone and the top of the Bifurcatus Zone (Fig. 2B). First sedimentological and stratigraphical studies of the Calcaire de Tonnerre Formation were carried out by Lambert (1893), Loreau (1967) and Loreau \& Tintant (1968). This formation spans the Planula zone (Fig. 2B). The dominant facies is a pure micritic and chalky limestone $\left(99.5 \%\right.$ of $\left.\mathrm{CaCO}_{3}\right)$, but subordinate amounts of pelletal and oolitic packstones also occur. Pure oolitic facies are known as «Pierre de Tonnerre» (Loreau, 1967) but these facies are absent in the studied succession. Several small coral bioherms and coral-rich debris breccia facies have been described from the formation (Loreau \& Tintant, 1968), but the occurrence of coral edifices several metres thick are documented for the first time.

\section{Application of GPR in carbonate facies}

The potential of GPR as a tool for mapping and detecting shallow subsurface heterogeneities in different geological settings has been clearly demonstrated during the past decades (Pratt \& Miall, 1993; Jol et al., 2003, among others). In limestone series, it is assumed that changes in dielectric properties are mostly related to porosity or structural changes (Pratt \& Miall, 1993; Meschede et al., 1997; Asprion \& Aigner, 2000; Van Den Bril et al., 2007; Young et al., 2007). Recent works have also demonstrated the potential of GPR for investigating limestone cliffs in terms of fracture assessment (Jeannin et al., 2006; Deparis et 
al., 2007), but few attempts have been made to determine the bedding geometries in carbonate series. Pratt and Miall (1993) document the internal architecture of a reservoirscale grainstone shoal deposited during the Middle Silurian using a GPR. Asprion and Aigner (2000) demonstrated the possibility of using this tool for carbonate facies recognition in Upper Jurassic limestones, especially coral buildups. Dagallier et al. (2000) outlined several depositional units (high-energy grainstones and low-energy mudstone) and different carbonate lithologies with GPR reflections in Upper Jurassic limestones. Grasmueck et al. (2004) used GPR to image in 3D decimetre-scale to metre-scale sedimentary structures in a Pleistocene oolite shoal-barrier bar setting and demonstrated that GPR signals can image a complex shallow-subsurface anatomy.

Recently, Asprion et al. (2009) proposed a new approach, which consists of using GPR sections for extrapolating facies information and geometries from outcrops and wells in order to refine and extend the resolution of the medium-scale and small-scale complexities in facies architecture on the Tortonian carbonate ramp of Menorca. This approach, known as the outcrop analogue approach, is classically used in petroleum geology in order to characterize subsurface reservoirs (Hornung \& Aigner, 2002; Jorry et al., 2003; Pringle et al., 2004). Asprion et al. (2009) integrated for the first time sedimentology and geophysics to characterize facies and geometries of a carbonate platform

\section{MATERIALS AND METHODS}

\section{Sedimentological study}

Upper Oxfordian and lower Kimmeridgian carbonate rocks are exposed along a recent roadcut near the city of Tonnerre, in the Armancon valley in France (Figs 2A and 3). The 
geometry of the stratal terminations defines several unconformities and establishes the architecture of sedimentary packages and sequences. Erosional surfaces separate coral bioherms, prograding units, and depositional sequences. Facies from each sedimentary package (bioherm and inter-bioherm zones) have been mapped on photomosaics (Fig. 4). Petrographic analysis (textures, faunal content and diagenetic features) provides critical information for interpreting depositional environments. Relative palaeobathymetry estimates are based on the shape of corals (lamellar, branching and massive forms), the associated microfauna (algae, foraminifers) and macrofauna (sponges, serpulids, oysters, gastropods, brachiopods), and the nature of the matrix of the bioherms. Depositional sequences and unconformity surfaces can be used to follow the architectural evolution of the carbonate platform.

Plugs from outcrop, averaging about $3 \mathrm{~cm}$ in length and $2.5 \mathrm{~cm}$ in diameter, were dried at $50^{\circ} \mathrm{C}$ for two days. Permeability measurements were made using a PMI GP-262 Gas Permeameter housed at the University of Geneva. Porosity was measured by hydrostatic weighting according to the European norm EN1936. Carbonate contents were analyzed using a carbonate bomb (Müller \& Gastner, 1971; Droxler et al., 1988). About $2 \mathrm{~cm}^{3}$ of sample were placed into a sealed vessel and reacted with $10 \% \mathrm{HCl}(2.3 \mathrm{~mol} / \mathrm{l})$. The volume of $\mathrm{CO}_{2}$ released was compared to volumes released by reacting known amounts of $100 \%$ of $\mathrm{CaCO}_{3}$

\section{GPR processing and interpretation}

GPR measurements were performed using a GSSI (Geophysical Survey System Inc.) SIR 3000 system with 200 and $400 \mathrm{MHz}$ shielded antennas operating in monostatic mode (a single antenna is used to transmit and to receive the electromagnetic pulses). In addition, the 
topography was measured every $10 \mathrm{~m}$ along the profiles with differential global positioning system (D-GPS).

The GPR surveys were made on outcrop DEV1 (Fig. 3). Profiles conducted on the top of the hill were far enough from the cliff to prevent side-effect, but close enough to allow a direct correlation between GPR images and outcrops. The GPR was dragged along the ground at a slow and constant walking speed. A 40 scans/s rate was selected in order to a posteriori enhance the signal/noise ratio with a stack operation when normalizing the GPR profiles in distance.

The GPR processing sequence is summarized in Table 1. The data were processed using the Reflexw package (Sandmeier Scientific Software; Sandmeier, 2007). Several filtering and gain adjustment operations were performed to enhance the data quality. Timezero correction aligned the traces to the same point in time. The first observed reflection (airground reflection) was used for this step. Low frequency system-dependent noise and highamplitude permanent temporal noise have been removed by applying Dewow and Background Removal filters, respectively (Table 1). Profiles were bandpass-frequency filtered, centered on $120 \mathrm{Mhz}$ (corresponding to the nominal return frequency of the $200 \mathrm{MHz}$ profiles). The bandpass frequencies are given in Table 1. To compensate for the EM energy attenuation with time, an energy decay gain correction was applied.

Topography correction and migration operations were employed to capture the true geometry of heterogeneities and interfaces with respect to depth. Migration is a mathematical operation which consists of precisely relocating reflectors at depth (or in time), i.e. the energy of the reflection is tracked back to its source. Frequency/wave number migration was conducted in the spectral mode with a constant velocity.

The outcrop calibration of the GPR data on remarkable reflectors at different depths gives an average $0.12 \mathrm{~m} / \mathrm{ns}$ EM wave velocity which is typical within these media (Reppert et 
al., 2000; Neal, 2004). This survey provides good quality data up to 340 ns two-way travel time (TWT) with the $200 \mathrm{MHz}$ central frequency antenna for the P1 profile. Based on this calibration, up to $20 \mathrm{~m}$ penetration depth was reached using the $200 \mathrm{MHz}$ antenna. The GPR profiles were interpreted with the Kingdom Suite package (Seismic Micro-Technology, Inc.), in terms of radar facies and radar surfaces, according to Neal (2004).

\section{RESULTS}

\section{Sedimentological description}

DEV1 and DEV2 outcrops, located along the Tonnerre roadcut, show the superposition of several accretional units separated by erosional surfaces (Fig. 4). These units are composed of decimetre-thick to metre-thick carbonate beds prograding toward the south-west. Several coral-dominated buildups with steep flanks are intercalated in prograding units (Fig. 4).

Lateral to the coral bioherms, bioclastic grainstones and coral rudstones with a peletoidal grainstone matrix prograde toward the south forming beds with an average dip of $15^{\circ}$ (Fig. 4). The top of this unit is bounded by the unconformity DT2, which truncates both the R3 bioherm and the rudstone flank beds (Fig. 4). Another prograding body, capped by an erosive surface (DT3) corresponds to well-stratified coarse-grained packstones arranged in large sigmoid prograding beds (Fig. 5A). This prograding interval contains some wellpreserved branching corals and large blocks composed of a coral-dominated framework. This attests to the erosion of corals and the accumulation of coral rubble (variable in size) along the bioherm talus. The other units are mostly dominated by sub-horizontally stratified wackestone/mudstone facies. The top of these accretionary units, whose bases and tops are 
bounded by unconformities DT4 and DT5, is characterized by medium-scale channels eroding the uppermost beds of the Calcaire de Tonnerre Formation. These channels are filled with mudstones. At their base, a lag deposit is constituted by a poorly sorted bioclastic facies, made up of peloids, skeletal fragments (500 $\mu \mathrm{m}$ to $2 \mathrm{~cm}$ in size), and coral debris. The erosional surface corresponds to the unconformity DT6.

Coral buildups are variable in size (Fig. 4). The biggest bioconstruction on the outcrop DEV1 is a $20 \mathrm{~m}$ wide and $20 \mathrm{~m}$ high buildup with a high biotic diversity. An unconformity surface (DT1) divides this unit in two amalgamated coral bioherms (R1 and R3). The R1 buildup is exclusively composed of dish corals with a mudstone matrix (Fig. 4C: facies f1). Branching and massive corals, with peletoidal packstone and grainstone matrix, dominate the R3 bioherm (Fig. 4C: facies f3). On the flanks, the facies consists of well-stratified, bioclastic grainstones and coral rudstones with a peletoidal grainstone matrix (Fig. 4C: facies f2). Smaller bioherms are also visible at the base of the outcrop DEV1. The R2 bioherm shows a coral assemblage similar to that of the R1 coralbuildup. The R4 bioherm is characterized by abundant thick and large dish corals with a bioclastic packstone to grainstone matrix. Facies on the north-eastern part of this bioherm grade to prograding flanking beds of packstones with a bioclastic packstone matrix composed of materials derived from the R4 buildup. The top of the R4 buildup is an irregular erosion surface that truncates both corals and internal sediment, and it is overlain by packstones (Fig. 5B). This unconformable surface occurred after lithification of the internal sediment.

The outcrop DEV2, located on the other side of the roadcut, shows coral-dominated bioherms and off-bioherm prograding facies that can be correlated to sequence boundaries (DT1 to DT5), but the general architecture significantly differs from the DEV1 outcrop (Fig. 4). It appears that bioherms are scattered and no linear trend (bioherm track) exists. 
The complexity of the platform architecture is accentuated by the occurrence of bioherms dominated by branching coral (R3, R5, and R6 buildups) above the DT2 and DT4 sequence boundaries (Figs 4 and $5 \mathrm{C}$ ). Branching corals are similar to the DEV1 R3 bioherm and are mostly Calamophylliopsis sp. and Pseudocoenia sp. (Fig. 4C: facies f3). Interbioherm facies are composed of packstones-grainstones that occasionally contain decimeter-sized blocks (Fig. 4C: facies f2). At the DEV2 outcrop, some metre-sized blocks occur below the R3 and R6 bioherms at DEV2 (Fig. 5C). The coral rubble below the R6 buildup might be synchronous with those observed at DEV1. The presence of coral debris confirms that high-energy conditions prevailed during the depositional sequence separated by DT2 and DT3 unconformities.

The lateral facies changes in the two outcrops demonstrate the complexity of the bioherm architecture. The growth of dish coral-dominated bioherms is synchronous and laterally homogeneous to the carbonate platform, while branching coral-dominated bioherms constitute more isolated structures with a limited lateral distribution. In general, the presence of large blocks and grainstone/packstone facies in the inter-bioherm areas confirm that the coral buildups grew in moderate to high-energy settings. The buildup succession is capped by the DT5 boundary which is overlain by mudstones/wackestones (Fig. 4C: facies f4).

\section{Sequence stratigraphy}

Six depositional sequences have been identified within the upper Oxfordian Calcaire de Tonnerre Formation. Each sequence is characterized by a succession of accretional units. Figure 6 illustrates the architecture of the carbonate platform from sequence S1 to sequence S6. 
a. Sequence $1(\mathrm{~S} 1)$

i. Facies and Biota: This sequence is characterized by the early settlement of R1 and R2 dish coral buildups (Microsolenidae and Actinaraea sp.) in low-energy conditions. Associated fauna is dominated by calcisponges (Chaetetidae), gastropods, some bioclasts encrusted by nubeculariids, and blue-green algae (Cayeuxia sp.). A coarse bioclastic flank facies accumulated around the incipient bioherms.

ii. Stratal Geometries: The dish corals constructed bioherms several metres wide. The R1 buildup can be subdivided into several accretionary units that are separated by undulating erosional surfaces. Coarse bioclastic debris accumulated as prograding packstone flanks.

iii. Bounding Surface Description: The top of this sequence is bounded by the unconformity DT1 on top of R1 and R2 bioherms.

iv. Interpretation: Lateral accumulation of coarse bioclastic packstones indicates synsedimentary erosion of the bioherms. The major change in the coral community above the DT1 unconformity (see description of facies and biota of Sequence S2) attests to a significant fall of the relative sea level at DT1.

b. Sequence 2 (S2)

i. Facies and Biota: Growth of the first branching corals in the R3 buildup occurred in high-energy conditions. Branches are sparsely encrusted by micrite (thrombolites?) and by calcisponges. Lateral facies are prograding packstones/grainstones containing common coral fragments. Coral rubble containing metre-sized blocks of dish coral facies accumulated on the flanks of the R3 buildup (visible at outcrop DEV2).

ii. Stratal Geometries: The internal architecture of the R1-R3 bioherm on DEV1 outcrop is characterized by superimposed aggradational coral-dominated packages. The branching coral-dominated buildups are flanked by stratified grainstone facies. 
iii. Bounding Surface Description: The top of this sequence is the DT2 unconformity which truncates clinobeds deposited during the previous sequence S1.

iv. Interpretation: The lateral facies transition into prograding packstones containing common coral fragments indicates synsedimentary erosion of the R1-R3 bioherm. The bioherm aggradation reflects a progressive sea-level rise, attesting to a keep-up growth strategy (Kendall \& Schlager, 1981).

c. Sequence 3 (S3)

i. Facies and Biota: This sequence is characterized by the deposition of beds containing large fragments of buildup material, mainly represented by branching and massive corals. The top of a large block at DEV1 is encrusted by oysters. Growth of a new bioherm (R4) attests to the proliferation of encrusting and unbored dish (Actinaraea sp.) and massive corals.

ii. Stratal Geometries: Two accretional units can be recognized. The R4 bioherm is a well-cemented bioherm which has a sharp contact with the lateral prograding flank. Flank accumulation is characterized by prograding sedimentary inclined beds containing large coral fragments.

iii. Bounding Surface Description: The top of this depositional sequence is the truncating DT3 sequence boundary.

iv. Interpretation: The accumulation of coral rubble from erosion of the coral bioherms attests to continuous high-energy conditions. The encrustation by oysters at the top of some blocks indicates a decreased sedimentary rate or periods of quiescence. The presence of overturned branching corals in the prograding wedges confirms active erosion of the higher part of the R3 buildup.

d. Sequence 4 (S4)

i. Facies and Biota: This sequence is composed of packstones/grainstones, 
branching and massive-coral reef facies, and mud-rich carbonates with a diverse fauna including massive corals (Thamnasteria lomontiana) growing on Trichites shells. Inter and off-bioherm facies are composed of coarse bioclastic packstones/grainstones containing coral fragments.

ii. Stratal Geometries: Aggrading coral facies contribute to the development of two plurimetric bioherms (R5 and R6) characterized by steep flanks. The bioherms are separated by fringing inclined beds. The muddy accretionary unit is poorly stratified. The progradation of large inclined beds continues to the south-west.

iii. Bounding Surface Description: The sequence is bounded at its top by the DT4 sequence boundary, showing considerable sediment removal.

iv. Interpretation: This unit represents sedimentation in quieter areas surrounded by coral bioherms, with a low sedimentation rate, where carbonate mud precipitation and deposition occurred (Loreau, 1975, 1979, 1982). The initial development of coral colonies suggests a stable substratum of Trichites shells that were fixed into the sediment. The geometry of the sequence boundary suggests that the sedimentary package is only a relic of a thicker depositional sequence which includes subaqueous interdune environments (dominated by mud-rich carbonates). A capping DT4 sequence boundary records a significant fall in relative sea level.

\section{e. Sequence 5 (S5)}

i. Facies and Biota: This depositional sequence is dominated by the deposition of mudstones/wackestones that are devoid of coral fragments and of other skeletal components. Bioherms that grew laterally are dominated by branching (phacelloid Calamophylliopsis sp. and ramose Pseudocoenia sp.) and massive corals.

ii. Stratal Geometries: The muddy deposits onlap and downlap onto the DT4 unconformity. A significant period of coral growth constructed the plurimetric R6 
bioherm which is composed of several coral packages.

iii. Bounding Surface Description: The top of this depositional sequence is bounded by the DT5 sequence boundary, the last sequence boundary visible at outcrops. This boundary pinches on the DT4 unconformity.

iv. Interpretation: The occurrence of a high proportion of carbonate mud in this depositional facies indicates a period of accommodation increase which corroborates the keep-up of branching coral bioherms.

\section{f. Sequence 6 (S6)}

i. Facies and Biota: This last exposed depositional sequence is characterized by mudstones/wackestones and poorly sorted bioclastic limestone composed of $500 \mu \mathrm{m}$ to $2 \mathrm{~cm}$ bioclasts and large debris of Diceras.

ii. Stratal Geometries: Horizontally bedded mudstones/wackestones onlap the DT5 unconformity and bury all bioherms. Small metre-scale channels erode the top of the platform.

iii. Bounding Surface Description: The top of this depositional sequence is bounded by the DT6 sequence boundary and is characterized by plurimetric channels that erode the top of the Upper Oxfordian carbonate platform.

iv. Interpretation: The erosive channels found on top of the Calcaire de Tonnerre indicate a period of low relative sea level. Wave-driven or tide-driven currents might have induced the occurrence of such channels.

Sequence S7 characterizes the burial of the carbonate platform at the base of the Kimmeridgian, with the occurrence of lagoonal sedimentation (Fig. 6). The architecture of the depositional sequences and sequence boundaries outline the depositional scheme of the upper Oxfordian carbonate platform near Tonnerre. Figure 6 presents an interpretation of the 
development of the successive sequences, including processes, resulting geometries and inferred oscillations of the relative sea level. Relative sea-level fluctuations produced major changes in carbonate production, expressed by the occurrence of different coral communities. The development of coral bioherms was active during time intervals characterized by highstands of the relative sea level. Branching coral-dominated bioherms preferentially grew after significant drops in relative sea level, as occurred at sequence boundaries DT1 and DT4. The exclusive occurrence of these keep-up bioherms indicates high-energy conditions and a reduced water depth (few metres) on top of the buildups. The concurrence of branching and thick-braided platy coral-dominated bioherms during the S3 sequence indicates a period of high sedimentation rate. Branching coral bioherms prevailed in shallow water settings and at the same time, thick-braided Actinarea buildups grew in deeper and more turbid conditions at the base of prograding bioclastic clinoforms. Other sequence boundaries, i.e. DT3 and DT5, resulted from erosion during minor drops in relative sea level. Within sequences, internal erosion surfaces are mostly interpreted as the result of erosion initiated by storms or by changes in current regimes.

\section{Calibration of GPR facies with outcrop lithofacies}

GPR profile P1 (Fig. 7) located at the top of the cliff DEV1 is directly correlated with the $25 \mathrm{~m}$ high outcrop. The $200 \mathrm{MHz}$ antenna reached $340 \mathrm{~ns}$ TWT corresponding to a $20 \mathrm{~m}$ depth penetration with a velocity of $0.12 \mathrm{~m} / \mathrm{ns}$. The raw data show very little noise. An analysis of this GPR profile together with a detailed sedimentological description of the different outcropping units allows bedding planes and major erosion surfaces (i.e. sequence boundaries) to be recognized and sedimentary facies characterized by distinct GPR surfaces and facies to be distinguished (Fig. 8). 
Coral buildups have visible internal bedding in the outcrop. The associated reflection pattern is mostly characterized by numerous strong and discontinuous reflections variable in amplitude (Fig. 7 and Fig. 8, Box A). They might be generated by non-uniform cementation and heterogeneous matrix content of the bioherms. Furthermore, zones of flat and convexdominated reflection shapes can be distinguished and appear to correspond to dish and branching coral dominated buildups, respectively (Figs 7 and 8, Box A). The presence of an eroded megaboulder (coral rubble) at outcrop DEV1 (Fig. 5) produces a radar facies with hyperbolic shaped reflections.

The deposition of prograding bioclastic facies lateral to the coral bioherms results from growth and erosion of the bioherms. Radar facies, characterized by mostly continuous, sub-tabular to sigmoid/oblique reflectors with various amplitude widths and frequencies, illustrate the accumulation of bioclastic facies on the buildup flanks and within inter-buildup depressions (Figs 7 and 8; Box B). Major erosive unconformities within the flanked prograding facies can be also distinguished on GPR profiles. The basal contact is generally oblique or tangential, while the upper contact is onlapping or toplapping. These major unconformities are characterized by high amplitude reflections and can be easily identified and picked by pointing lateral reflector terminations.

Medium-scale channels were identified on the GPR profile P1 carried out on the top of the outcrop DEV1 (Fig. 3), using a $200 \mathrm{Mhz}$ antenna. Focused on these channels, a $50 \mathrm{~m}$ long survey using a $400 \mathrm{Mhz}$ antenna (P2) details the internal structure of the channel fill (Figs 7 and 8; Box D). The channels have an erosive base and are characterized by continuous, sub-parallel concave reflections (less and less concave from base to top) that onlap the channel flanks. These geometrical features, corresponding to channel-filled sequences, are exclusively derived from mudstone infill. Below the channels, this GPR survey also revealed the presence of localized, strong and discontinuous, convex shaped, 
high amplitude reflections, which can be interpreted as coral buildups.

The cap mudstone facies occur at the top of the facies succession and overlay carbonate buildups and their prograding flanked facies. At the outcrop, they include wellstratified thin-bedded mudstones which contain very few disseminated bioclasts. Prominent, moderately continuous reflector lines are interpreted to correspond to the thin-bedded mudstones at the top of the cliff. GPR profiles also show moderately concave to hummocky shapes with onlap terminations on the flanks and some indications of basal truncation. Based on geophysical data analysis and sedimentological information, these cap mudstones may be a large-scale erosive sequence at the top of the upper Oxfordian facies (Figs 7 and 8; Box C). Two main reflection-free zones at the beginning and at the end of P1 (Fig. 7) coincide with the presence of a thin top soil layer which strongly attenuates the EM wave energy.

Some of the identified radar facies have been sampled for petrophysical analyses (Fig. 7). Table 2 summarizes the main petrophysical properties of several facies collected in prograding flanking units, lamellar coral bioherms, and a muddy channelling depositional sequence. The measurements indicate that the plugs are $100 \% \mathrm{CaCO}_{3}$. The absence of any electrically conductive particles such as clay in the Calcaire de Tonnerre Formation may explain the large penetration depth which has been reached in this case study. Also, it appears that porosity and permeability show significant intra-unit variability (Table 2). The good correspondence between outcrop bedding and GPR reflections indicates that each accretionary unit has rather constant petrophysical properties. In that case, it means that porosity and permeability values measured at specific locations do not reflect the global petrophysical behaviour of the accretionary units. Intra-unit gradual changes of porosity and permeability might also be considered, without any consequence on the generation of significant reflections. Nevertheless, porosity and permeability contrasts are also observed between accretionary units which tend to confirm an inter-unit petrophysical variability. 


\section{Geometries and facies occurrence in subsurface}

Once GPR facies are calibrated with outcrop lithofacies, the objective is to identify depositional geometry and facies below the outcropping unit of the Calcaire de Tonnerre. In particular, the base of the outcropping coral bioherms requires imaging. The following questions need to be addressed: 1 ) Is there a drastic change in terms of depositional facies and environment through the Calcaire de Tonnerre Formation? 2) Does the base of coral bioherms visible at outcrop correspond to the base of the coral edifices? 3) If not, what is the nature and the submarine topography of the substratum at the base of the bioherms?

In order to answer these questions, an additional GPR survey (P3) has been conducted at the base of the cliff DEV1 (Fig. 3). This survey shows a penetration depth of 11 $\mathrm{m}$, corresponding to a $190 \mathrm{~ns}$ twt range with a velocity of $0.12 \mathrm{~m} / \mathrm{ns}$ (Fig. 9). Different GPR facies, geometry, and unconformities can be distinguished and are in good continuity with profile P1. Based on the previous outcrop calibration, this survey indicates that the same depositional settings prevailed before the growth of the coral bioherms. Radar facies can be interpreted as dominant high-energy bioclastic facies, organized in large-scale prograding sequences which are delimited by erosive unconformities (Figs 8 and 9; Box F). Also, erosive bases and sigmoid beds underline several medium-scale to large-scale channels (Figs 8 and 9; Box E). No major coral bioherms are detected on this profile P3.

The superposition of both GPR profiles acquired at the top and base of the outcrop DEV1 gives a 30 to $40 \mathrm{~m}$ thick image of the whole carbonate section (Fig. 10). On profile P3, some interfaces are characterized by strong and continuous reflections, one in particular is visible all along the profile. This reflector suggests major erosion on top of bioclastic beds and can be interpreted as a palaeotopographic surface upon which the outcropping coral 
reefs settled.

\section{DISCUSSION}

Implications for Upper Jurassic reefs

This case study is the first to examine the complete evolution of a facies belt dominated by coral buildups (from the initiation of submarine highs to the platform infilling) in a pure carbonate environment from the Late Jurassic. The geometry of the depositional profile from the Tonnerre platform was dominantly controlled by variations in relative sea level, which induced major erosional events at sequence boundaries, and bioherm aggradation during periods of accommodation increase. Autocyclic processes (such as storms or a change in current regime) might have contributed to the bioherms' erosion, leading to the accumulation of coral rubble along the bioherm flanks.

Moreover, considering that the Calcaire de Tonnerre Formation was deposited during the Planula zone, it appears reasonable to propose a time range for deposition of about 500 ka, during which five sea-level falls have been recognized. Taking into account that bioherms grew on a tectonically stable and wide shelf of the northern Tethys, the high-frequency, moderate to low amplitude eustatic fluctuations that have been detected in the outcrop were probably not driven by tectonic pulses.

The formation of continental ice is known as the most efficient mechanism to account for rapid, global-scale sea-level fall. Taking into account cooling events that are known to have occurred in the Late Jurassic (Veizer et al., 2000; Dromart et al., 2003) and the highfrequency oscillations in relative sea level during the 500 kyrs of carbonate deposition from Tonnerre, it is suggested that the stratigraphic architecture of carbonate platforms in the late 
Oxfordian might be driven by eustatic sea-level changes. The succession of bioherm aggradation and of lowstand erosion events indicated by this study perfectly fits with the concept of glacio-eustatism in icehouse mode. These new findings have important implications to improve knowledge on the Late Jurassic climate, which has most likely contributed to the wide development of corals on pericontinental and epeiric Tethyan seas. Cecca et al. (2005) recently mentioned that detailed palaeoecological studies of periequatorial Oxfordian reefs are urgently needed for a more accurate time resolution of Oxfordian palaeoclimatic changes.

\section{Implications for imaging carbonate platforms using GPR}

The penetration depths gained in this study $(20 \mathrm{~m}$ with a monostatic $200 \mathrm{MHz}$ antenna) seem to be rather uncommon. Except for the results of Asprion et al. (2009), such penetration depths have not been reported for this frequency within carbonate sequences. Moreover, these results indicate a penetration depth at least equal to those gained with 25 to $100 \mathrm{MHz}$ antennas in several studies devoted to carbonate facies (Pratt \& Miall, 1993; Grasmueck et al., 2004; Neal, 2004), with two times the resolution (vertical resolution is 25 $\mathrm{cm}$ here, with a $120 \mathrm{MHz}$ return central frequency). The high penetration depths can be related to a pure carbonate setting (up to $100 \% \mathrm{CaCO}_{3}$ content for the whole sequence, no clay within the bedding planes) and to a very reduced to non-existent top soil layer (i.e. GPR antennas were in direct contact with the cap rock), resulting in very low loss at the nearsurface. The influence of this last parameter is demonstrated at the beginning of the P1 profile (Fig. 7), where the presence of a thin top soil layer strongly attenuates the GPR response. These penetration depths are comparable to those obtained during fracture studies of Urgonian limestone cliffs in SE France (Jeannin et al., 2006; Deparis et al., 2007). 
These particular surveys were conducted on cliffs, perpendicular to the bedding planes, with unshielded antennas. Except for the antennas which lose less energy when unshielded, the absence of a soil layer, near-surface moisture, salts, interstitial clay and a clayey bedding plane (i.e. similar conditions to the current study) can be considered essential conditions for reaching a good penetration depth and therefore for elaborating the most accurate geological prediction when no outcrop exposures are available. This work presents an observation scale intermediate between outcrop scale (some metres to some tens of metres) and seismic scale (several hundreds of metres to some kilometres).

\section{CONCLUSIONS}

The integration of sedimentological and geophysical techniques can improve a sedimentological model where no outcrop exposures are available. The successful highresolution 2D GPR survey dedicated to the biohermal and peri-biohermal Calcaire de Tonnerre Formation offers new insight into the spatial distribution of sedimentary features of a carbonate platform. A penetration depth of $20 \mathrm{~m}$ with a monostatic $200 \mathrm{MHz}$ antenna allowed the internal architecture of a complex facies belt composed of scattered bioherms and variable inter-bioherm detrital facies (from high-energy rudstones to low-energy packstones) to be imaged. In the subsurface, it provided the imaging of a major palaeotopographic surface which acted as a substratum for the development of coral bioherms.

This study illustrates that relationships exist between the growth of Late Jurassic coral bioherms and topographic highs, and confirms that Late Jurassic corals were able to respond quickly to both a major change in sedimentation rate and/or a relative sea-level oscillation. In the frame of Late Jurassic icehouse conditions, this study suggests that the 
rapid palaeoenvironmental changes which have been detected on outcrops might be directly correlated with Upper Oxfordian eustatic sea-level fluctuations.

\section{ACKNOWLEDGEMENTS}

The authors dedicate this work to Jean-Paul Loreau (1940-2004), Professor of Geology at the University of Burgundy and Director of the Earth Sciences Department of Dijon. We are grateful to the University of Geneva for having provided us with equipment for the sampling of plugs at outcrop and for the measurements of porosity and permeability at their petrophysical laboratory. We express our gratitude to Milan Berès (University of Geneva) for his help in geophysical processing of our data, to Guy Cabioch (IRD Nouméa) and Elias Samankassou (University of Geneva) for their suggestions and comments on the sedimentological study. We also thank Jacques Deparis (BRGM) and David Goutaland (CETE de Lyon) for their comments on this study. Luis Pomar, an anonymous reviewer, and Associate Editor Gregor Eberli are acknowledged for their constructive review and comments, which improved the original manuscript.

\section{REFERENCES}

Asprion, U. and Aigner, T. (1999) Towards realistic aquifer models: three-dimensional georadar surveys of Quaternary gravel deltas (Singen Basin, SW Germany). Sedimentary Geology, 129, 281-297.

Asprion, U. and Aigner, T. (2000) An initial attempt to map carbonate buildups using ground-penetrating radar: an example from the Upper Jurassic of SW Germany. Facies, 42, 245-252. 
Asprion, U., Westphal, H., Nieman, M. and Pomar, L. (2009) Extrapolation of depositional geometries of the Menorcan Miocene carbonate ramp with ground-penetrating radar. Facies, 55, 37-46.

Badenas, B., Aurell, M., and Gröcke, D.R. (2005) Facies analysis and correlation of highorder sequences in middle-outer ramp successions: variations in exported carbonate on basin-wide delta C-13(carb) (Kimmeridgian, NE Spain). Sedimentology, 52, 1253-1275.

Beres, M., Green, A.G., Huggenberger, P. and Horstmeyer, H. (1995) Mapping the architecture of glaciofluvial sediments with three-dimensional georadar. Geology, 23, 1087-1090.

Beres, M. and Haeni, F.P. (1991) Application of ground-penetrating-radar methods in hydrogeologic studies. Ground Water, 29, 375-386.

Beres, M., Huggenberger, P., Green, A.G. and Horstmeyer, H. (1999) Using two- and three-dimensional georadar methods to characterize glaciofluvial architecture. Sedimentary Geology, 129, 1-24.

Berner, R.A. (1994) Geocarb II: a revised model of the atmospheric CO2 over Phanerozoic time. American Journal of Science, 294, 56-91.

Bertling, M. and Insalaco, E. (1998) Late Jurassic coral/microbial reefs from the northern Paris Basin: Facies, Palaeoecology and Palaeogeography. Palaeogeography, Palaeoclimatology, Palaeoecology, 139, 139-175.

Cecca, F., Lathuilière, B., Marchand, D., Gardin, S. and Bartolini, A. (2001) Enregistrements paléobiologiques et paléoécologiques de fluctuations paléoclimatiques a l'Oxfordien (Jurassique supérieur). In: Paléodiversité, Crise, Paléoenvironnement (Ed A.M. Lezine). Séance spécialisée de la Société Géologique de France, Paris, pp. 19-21.

Cecca, F., Martin Garin, B., Marchand, D., Lathuiliere, B. and Bartolini, A. (2005) Paleoclimatic control of biogeographic and sedimentary events in Tethyan and periTethyan areas during the Oxfordian (Late Jurassic). Palaeogeography, Palaeoclimatology, Palaeoecology, 222, 10-32.

Chevalier, F., Garcia, J.P., Quesne, D., Guiraud, M. and Menot, J.C. (2001) Corrélations et interprétations génétiques dans les formations récifales oxfordiennes de la haute vallée de I'Yonne (sud-est du Bassin de Paris, France). Bulletin de la Société Géologique de France, 172, 69-84. 
Dagallier, G., Laitinen, A.I., Malartre, F., Van Campenhout, I.P.A.M. and Veeken, P.C.H. (2000) Ground penetrating radar application in a shallow marine Oxfordian limestone sequence located on the eastern flank of the Paris Basin, NE France. Sedimentary Geology, 130, 149-165.

Deparis, J., Garambois, S. and Hantz, D. (2007) On the potential of Ground Penetrating Radar to help rock fall hazard assessment: A case study of a limestone slab, Gorges de la Bourne (French Alps). Engineering Geology, 94, 89-102.

Dromart, G., Garcia, J.P., Picard, S., Atrops, F., Lecuyer, C. and Sheppard, S.M.F. (2003) Ice age at the Middle/Late Jurassic transition? Earth and Planetary Science Letters, 213, 205-220.

Droxler, A.W., Morse, J.W. and Kornicker, W.A. (1988) Controls on carbonate mineral accumulation in Bahamian basins and adjacent Atlantic Ocean sediments. Journal of Sedimentary Petrology, 11, 120-130.

Ellis, P.M., Wilson, R.C.M. and Leinfelder, R.R. (1990) Carbonate Platforms; facies, sequences and evolution. In: Controls on Upper Jurassic carbonate buildup development in the Lusitanian Basin, Portugal (Eds M.E. Tucker, J.L. Wilson, P.D. Crevello, J.R. Sarg and J.F. Read), 9, pp. 169-202. International Association of Sedimentologists.

Goutaland, D., Winiarski, T., Dubé, J.S., Bièvre, G., Buoncristiani, J.F., Chouteau, M. and Giroux, B. (2008) Hydrostratigraphic characterization of glaciofluvial deposits underlying an infiltration basin using ground-penetrating radar. Vadose Zone Journal, 7, 114.

Grasmueck, M. and Weger, R. (2002) 3D GPR reveals complex internal structure of Pleistocene oolitic sandbar. The Leading Edge, 21, 634-639.

Grasmueck, M., Weger, R. and Horstmeyer, H. (2004) Three-dimensional groundpenetrating radar imaging of sedimentary structures, fractures, and archaeological features at submeter resolution. Geology, 32, 933-936.

Gröcke, D.R., Price, G.D., Ruffell, A.H., Mutterlose, J. and Baraboshkin, E. (2003) Isotopic evidence for Late Jurassic-Early Cretaceous climate change. Palaeogeography, Palaeoclimatology, Palaeoecology, 202, 97-118. 
Gygi, R.A. (1986) Eustatic sea level changes of the Oxfordian (Late Jurassic) and their effects documented in sediments and fossil assemblages of an epicontinental sea. Eclogae Geologicae Helvetiae, 79, 455-491.

Gygi, R.A. and Persoz, F. (1986) Mineralostratigraphy, litho- and biostratigraphy combined in correlation of the Oxfordian (Late Jurassic) formations of the Swiss Jura range. Eclogae Geologicae Helvetiae, 79, 385-454.

Haq, B.U., Hardenbol, X. and Vail, Y. (1988) Mesozoic and Cenozoic chronostratigraphy and cycles of sea-level change. In: Sea level changes, an integrated approach (Eds C.K. Wilgus, B.S. Hastings, C.A. Ross, H. Posamentier, J. Van-Wagoner and C.G. Kendall). SEPM Spec. Pub., 42, 72-108.

Heinz, J. and Aigner, T. (2003) Three-dimensional GPR analysis of various Quaternary gravel-bed braided river deposits (southwestern Germany). In: Ground Penetrating Radar in Sediments (Eds C. Bristow and H. Jol), Special Publications, 211, pp. 99-110. Geological Society, London.

Hoffman, A., Gruszczynski, M., Malkowski, K., Halas, S., Matyja, B.A. and Wierzbowski, A. (1991) Carbon and oxygen isotope curves for the Oxfordian of central Poland. Acta Geol. Pol., 43, 157-164.

Hornung, J. and Aigner, T. (2002) Reservoir architecture in a terminal alluvial plain: an outcrop analogue study (Upper Triassic, Southern Germany) Part II: cyclicity, controls and models. Journal of Petroleum Geology, 25, 151-178.

Huggenberger, P. and Regli, C. (2006) A sedimentological model to characterize braided river deposits for hydrogeological applications. In: Braided Rivers : Process, Deposits, Ecology and Management (Eds G.H. Sambrook-Smith, J. L. Best and C.S. Bristow), pp. 51-74 . Blackwell Publishing, Oxford, UK.

Insalaco, E. (1996) Upper Jurassic microsolenid biostromes of northern and central Europe : facies and depositional environment. Palaeogeography, Palaeoclimatology, Palaeoecology, 121, 169-194.

Jansa, L.F. (1986) Paleoceanography and evolution of the North Atlantic Ocean Basin during the Late Jurassic. In: The Geology of North America (Eds P.R. Vogt and B.E. Tucholke) Geol. Soc. Am., Boulder, CO, USA. 
Jeannin, M., Garambois, S., Grégoire, C. and Jongmans, D. (2006) Multiconfiguration GPR measurements for geometric fracture characterization in limestone cliffs (Alps). Geophysics, 71, B85-B92.

Jol, H.M., Bristow, C.S., Smith, D.G., Junck, M.B. and Putnam, P. (2003) Stratigraphic imaging of the Navajo Sandstone using ground-penetrating radar. The Leading Edge, 22 , 882-887.

Jorry, S.J., Davaud, E. and Caline, B. (2003) Controls on the distribution of Nummulites facis: A case study from the Late Ypresian El Garia Formation (Kesra Plateau, Central Tunisia. Journal of Petroleum Geology, 26, 283-306.

Kendall, C.G.S.C. and Schlager, W. (1981) Carbonates and relative changes in sea-level. Marine Geology, 44, 181-212.

Lambert, J. (1893) Etude stratigraphique sur le calcaire séquanien de Tonnerre. Mémoire de la Société Paléontologique Suisse, 20, 175-213.

Leinfelder, R.R. (1987) Formation and significance of Black Pebbles from the Ota Limestone (Upper jurassic, Portugal). Facies, 17, 159-170.

Leinfelder, R.R. (1989) Intrabecken-Karbonatplattformen und Riffstrukturen im Ostteil des Lusitanischen Beckens - Fallbeispiele aus dem Oberjura von Portugal, Habilitation Thesis, University of Mainz, Germany.

Leinfelder, R.R. (1992) A modern-type Kimmeridgian reef (Ota Limestone, Portugal); implications for Jurassic reef models. Facies, 26, 11-34.

Leinfelder, R.R. (1993) Upper Jurassic reef types and controlling factors. Profil, 5, 1-45.

Leinfelder, R.R. (1994) Karbonatplattformen und Korallenriffe innerhalb siliziklastischer sedimentationsbereiche (Oberjura, Lusitanisches Becken, Portugal). Profil, 6, 1-207.

Leinfelder, R.R. (2001) Jurassic reef ecosystems. In: The history and sedimentology of ancient reef systems (Ed J.D. Stanley, Jr.), pp. 251-309. Kluwer Academic/Plenum Publishers, New York, NY USA.

Leinfelder, R.R., Krautter, M., Laternser, R., Nose, M., Schmid, D., Scheigert, G., Werner, W., Keupp, H., Brugger, H., Herrmann, R., Rehfeld-Kiefer, U., Schroeder, R., Reinhold, C., Knock, R., Zeiss, A., Schweizer, V., Christmann, H., Menges, G. and 
Luterbacher, H. (1994) The origin of Jurassic reefs : current research developments and results. Facies, 31, 1-56.

Loreau, J.P. (1967) La Pierre de Tonnerre : Etude stratigraphique et petrographique dans le Jurassique superieur du tonnerrois, Mémoire de Diplôme d'Etudes Supérieures, Université de Paris, France.

Loreau, J.P. (1975) Les grands traits de la sédimentation sur l'emplacement de l'actuelle bordure sud-est du Bassin de Paris au Jurassique supérieur. IXme Congrès Int. Sédimentologie, Nice, Volume 9, Tome 5, Theme 2, 273-281.

Loreau, J.P. (1979) Nature calcitique initiale et diagenèse des oolithes jurassiques du Bassin de Paris. Ass. Sédiment. Fr. Spec. Publ., 1, 417-429.

Loreau, J.P. (1982) Sédiments aragonitiques et leur genèse. Mém. Muséum Hist. Nat. Paris, série $C, 47,312 \mathrm{p}$.

Loreau, J.P., Alabouvette, B., Mégnien, C., Mégnien, F. and Thierry, J. (1970) Tonnerre : Carte géologique de la France à 1/50 000, BRGM, Orléans, France.

Loreau, J.P. and Tintant, H. (1968) Le calcaire de Tonnerre et les formations adjacentes du Jurassique supérieur de I'Yonne: Observations stratigraphiques et paléontologiques. Bulletin de la Société Géologique de France, X7, 341-357.

McMechan, G.A., Loucks, R.G., Zeng, X. and Mescher, P. (1998) Ground penetrating radar imaging of a collapsed paleocave system in the Ellenburger dolomite, central Texas. Journal of Applied Geophysics, 39, 1-10.

Menot, J.C. (1974) Sur l'organisation du système récifal inférieur Oxfordien aux confins de I'Yonne et de la Nièvre. Comptes Rendus de l'Académie des Sciences, 278, 1459-1462.

Menot, J.C. (1980) Formations récifales du Jurassique Supérieur de la vallée de I'Yonne. Geobios, Mémoire spécial, 4, 47-53.

Menot, J.C. and Rat, P. (1967) Sur la structure du complexe récifal jurassique supérieur de la vallée de l'Yonne. Comptes Rendus de l'Académie des Sciences, 264, 2620-2623.

Meschede, M., Asprion, U. and Reicherter, K. (1997) Visualisation of tectonic structures in shallow-depth high-resolution ground-penetrating radar (GPR) profiles. Terra Nova, 9, 167-170. 
Moore, G.T., Hayashida, D.N., Ross, C.A. and Jacobson, S.R. (1992a) Paleoclimate of the Kimmeridgian/Tithonian (Late Jurassic) world: I. Results using a general circulation model. Palaeogeography Palaeoclimatology Palaeoecology, 93, 113-150.

Moore, G.T., Sloan, L.C., Hayashida, D.N. and Umaigar, N.P. (1992b) Paleoclimate of the Kimmeridgian/Tithonian (Late Jurassic) world: II. Sensitivity tests comparing three different paleotopographic settings. Palaeogeography Palaeoclimatology Palaeoecology, 95, 229-252.

Müller, G. and Gastner, M. (1971) The "karbonat-bombe", a simple device for the determination of the carbonate content in sediments, soils and other materials. Neus Jahrbuch Fur Mineralogie, 10, 466-469.

Neal, A. (2004) Ground-penetrating radar and its use in sedimentology: principles, problems and progress. Earth-Science Reviews, 66, 261-330.

Olivier, N., Carpentier, C., Martin-Guérin, B., Lathuilière, B., Gaillard, C., Ferry, S., Hantzpergue, P. and Geister, J. (2004) Coral-microbialite reefs in pure carbonate versus mixed carbonate-siliciclastic depositional environments; the example of the Pagny-surMeuse section (upper Jurassic, northeastern France). Facies, 50, 229-255.

Olivier, N., Hantzpergue, P., Gaillard, C., Pittet, B., Leinfelder, R., Schmid, D.U. and Werner, W. (2003) Microbialite morphology, structure and growth: a model of the Upper Jurassic reefs of the Chay Peninsula (western France). Palaeogeography, Palaeoclimatology, Palaeoecology, 193, 383-404.

Oschmann, W. (1988) Kimmeridge clay sedimentation - a new cyclic model. Palaeogeography Palaeoclimatology Palaeoecology, 65, 313-332.

Oschmann, W. (1990) Environmental cycles in the late Jurassic northwest European epeiric basin; interaction with atmospheric and hydrospheric circulations, In: Processes and Patterns in Epeiric Basin (Eds T. Aigner and R.H. Dott), Sedimentary Geology, 69, 331332.

Pittet, B. (1996) Contrôles climatiques, eustatiques et tectoniques sur des systèmes mixtes carbonatés/siliciclastiques de plate-forme : exemple de l'Oxfordien (Jura Suisse, Normandie, Espagne). PhD Thesis, Université de Fribourg, Switzerland. 
Pittet, B. and Strasser, A. (1998) Long-distance correlations by sequence stratigraphy and cyclostratigraphy : examples and implications (Oxfordian from the Swiss Jura, Spain, and Normandy). Geologische Rundschau, 86, 852-874.

Pittet, B., Strasser, A. and Mattioli, E. (2000) Depositional sequences in deep-shelf environments: a response to sea level changes and shallow-platform carbonate productivity (Oxfordian, Germany and Spain). Journal of Sedimentary Research, 73, 392407.

Pratt, B.R. and Miall, A.D. (1993) Anatomy of a bioclastic grainstone megashoal (Middle Silurian, southern Ontarion) revealed by ground-penetrating radar. Geology, 21, 223-226.

Price, G. and Gröcke, D.R. (2002) Strontium-isotope stratigraphy and oxygen- and carbonisotope variation during the Middle Jurassic- Early Cretaceous of the Falkland Plateau, South Atlantic. Palaeogeography Palaeoclimatology Palaeoecology, 183, 209-222.

Price, G. and Sellwood, B.W. (1997) "Warm" palaeotemperatures from high Late Jurassic palaeolatitudes (Falkland Plateau): ecological, environmental or diagenetic controls? Palaeogeography Palaeoclimatology Palaeoecology, 129, 315-327.

Pringle, J.K., Westerman, A.R., Clark, J.D., Drinkwater, N.J. and Gardiner, A.R. (2004) D high-resolution digital models of outcrop analogue study sites to constrain reservoir model uncertainty: an example from Alport Castles, Derbyshire, UK. Petroleum Geoscience, 10, 343-352.

Reppert, P.M., Dale Morgan, F. and Toksöz, M.N. (2000) Dielectric constant determination using ground-penetrating radar reflection coefficients. Journal of Applied Geophysics, 43, 189-197.

Ross, C.A., Moore, G.T. and Hayashida, D.N. (1992) Late Jurassic paleoclimate simulationpaleoecological implications for Ammonoid provinciality. Palaios, 7, 487-507.

Sandmeier, K.J. (2007) Reflexw 4.5 user guide. Sandmeier Scientific Softwares, Karlsruhe, Germany.

Sellwood, B.W. and Valdes, P.J. (1997) Geological evaluation of climate General Circulation Models and model implications. Terra Nova, 9, 75-78.

Sellwood, B.W., Valdes, P.J. and Price, G.D. (2000) Geological evaluation of multiple general circulation model simulations of Late Jurassic palaeoclimate. Palaeogeography Palaeoclimatology Palaeoecology, 156, 147-160. 
Strasser, A., Aurell, M., Bádenas, B., Meléndez, G. and Tomás, S. (2005) From platform to basin to swell: orbital control on sedimentary sequences in the Oxfordian, Spain. Terra Nova, 17, 407-413.

Valdes, P.J. and Sellwood, B.W. (1992) A paleoclimate model for the Kimmeridgian. Palaeogeography Palaeoclimatology Palaeoecology, 95, 47-72.

Van den Bril, K., Gregoire, C., Swennen, R., and Lambot, S. (2007) Ground-penetrating radar as a tool to detect rock heterogeneities (channels, cemented layers and fractures) in the Luxembourg Sandstone Formation (Grand-Duchy of Luxembourg). Sedimentology, 54, 949-967.

Veizer, J.Y., Goddéris, Y. and Francois, L.M. (2000) Evidence for decoupling of atmospheric $\mathrm{CO} 2$ and global climate during the Phanerozoic eon. Nature, 408, 698-701.

Vogt, P.R. and Tucholke, B.R. (1986) Perspective on the geology of the North Atlantic Ocean, In: The Geology of North America (P.R. Vogt and B.E. Tucholke, eds) Geol. Soc. Am., pp. 1-18, Boulder, CO, USA.

Wierzbowski, H. (2002) Detailed oxygen and carbon isotope stratigraphy of the Oxfordian in Central Poland. International Journal of Earth Sciences, 91, 304-314.

Wierzbowski, H. (2004) Carbon and oxygen isotope composition of Oxfordian-Early Kimmeridgian belemnite rostra: palaeoenvironmental implications for Late Jurassic seas. Palaeogeography Palaeoclimatology Palaeoecology, 203, 153-168.

Young, R.A., Staggs, J.G., Slatt, R.M. and Van Dam, R.L. (2007) Application of 1-D convolutional modeling to interpretation of GPR profiles - Turbidite Sandstone Channel 1, Lewis Shale, Wyoming. Journal of Environmental and Engineering Geophysics, 12, 241254.

Ziegler, P.A. (1988) Evolution of the Artic-North-Atlantic and the western Tethys. AAPG Mem., 43, 198 pp. 


\begin{tabular}{|c|c|c|}
\hline Process & Goal & Parameters (when applicable) \\
\hline \multicolumn{3}{|l|}{ Enhance signals } \\
\hline Stack & Remove high frequency noise & 4 traces \\
\hline Time zero correction & Align traces to same origin in time & Alignment of direct waves \\
\hline Dewow & Remove low-frequency system-dependent noise & $\begin{array}{l}\text { running mean value on the whole } \\
\text { signal (350 ns) }\end{array}$ \\
\hline Background removal & Remove constant temporal noise & $350 \mathrm{~ns}$ \\
\hline Bandpass filtering & Remove low and high frequency & LCO/LP/UP/OCO: 50/100/150/225 \\
\hline Gain correction & Compense EM energy attenuation with time & $\begin{array}{l}\text { Time energy decay } \\
\text { Scaling factor } 0.9\end{array}$ \\
\hline \multicolumn{3}{|l|}{ Geometry calibration } \\
\hline Migration & Time to depth conversion & $0,12 \mathrm{~m} / \mathrm{ns}$ \\
\hline Topography correction & Reflect the true topography & D-GPS measured each $10 \mathrm{~m}$ \\
\hline
\end{tabular}

Table 01: GPR data processing sequence concerning the $200 \mathrm{MHz}$ antenna. LCO: lower cutoff frequency, LP: lower plateau frequency, UP: upper plateau frequency, UCO: upper cut-off frequency. 


\begin{tabular}{lllll}
\hline Sample & Facies & $\mathrm{CaCO}_{3}(\%)$ & Permeability (mD) & Porosity (\%) \\
\hline Ton2 & P.F.F. & 100 & 5,07 & 9,15 \\
Ton2" & P.F.F. & 100 & 24,22 & 19,27 \\
Ton3 & L.C.B. & 100 & 23,09 & 26,43 \\
Ton3' & L.C.B. & 100 & 37,6 & 18,54 \\
Ton5 & M.C.F. & 100 & 2,31 & 17,21 \\
\hline
\end{tabular}

Table 02: Petrophysical measurements made on plugs. The location of samples on outcrop DEV1 is reported on Figure 7. P.F.F.: Prograding flanked facies; L.C.B.: Lamellar-coral buildup; M.C.F.: Muddy channelling facies. 


\section{FIGURE CAPTION}

Figure 1: Jurassic palaeogeography of the Atlantic region (after Vogt \& Tucholke, 1986) and the Northern Tethys domain (modified after Leinfelder, 1987, 1989; Ziegler, 1988; Ellis et al., 1990) and possible oceanic circulation pattern (modified after Oschmann, 1988, 1990; Jansa, 1986; Leinfelder, 1992, 1994). During this interval, the distribution of carbonate platforms extended widely along both margins of the Atlantic and northern Tethys oceans.

Figure 2: A: Geological map of the study area (after Loreau et al., 1970) with location of the studied outcrops. B: Biostratigraphic framework and relative sea-level fluctuations of the Upper Oxfordian. The stratigraphic succession of the ammonite zones is classically defined as a standard zonation for the sub-Mediterranean province (Insalaco, 1996). Ages at boundaries of ammonite zone have been integrated from Strasser et al. (2005).

Figure 3: Location of the studied outcrops. A: 3D aerial view of the studied area located at Tonnerre. Vertical exaggeration is $\times 2$. B: Aerial photograph showing outcrops (DEV1 and DEV2) and GPR profiles (P1, P2, and P3).

Figure 4: Evidence of coral-dominated bioherms and off-bioherm bioclastic deposits in the Calcaire de Tonnerre Formation. A: Panorama of the DEV1 outcrop located along the roadcut of Tonnerre and geometry of coral bioherms and of prograding wedges. The location of discontinuous boundaries is based on lateral bedding terminations (onlap, downlap and erosion top). B: Panorama of the DEV2 outcrop (facing DEV1) and geometry of coral bioherms and of prograding wedges. DEV 2 panorama and interpretation have been flipped about the vertical axis, showing the same orientation as outcrop DEV1. C: Correlation 
between two synthetic sections logged through the R1-R3 bioherms from both DEV1 and DEV2 outcrops. Section 1 shows two superimposed coral-dominated buildups, while interbioherm grainstones are intercalated between buildups on section 2. Facies f1: dish coraldominated facies; Facies f2: bioclastic grainstones containing coral rubble, skeletal debris, and peloids; Facies f3: branching coral-dominated facies showing a well preserved Calamophylliopsis sp. coral in life position; Facies f4: mudstone/wackestone facies composed of scattered echinoid debris and other bioclasts. Abbreviations R1, R2, R3, R4, R5 and R6 represent coral buildups. DT1, DT2, DT3, DT4 and DT5 are unconformity surfaces. Panels A, B and C are detailed on Figure 5.

Figure 5: Geometry of sedimentary packages in the Calcaire de Tonnerre Formation. A: Offbioherm prograding facies. These progradations may be a metre or more in height. This detail also shows that DT4 has been erosionally truncated by DT5. B: Evidence of erosion (marked by unconformity DT4) affecting the top of the R3 bioherm at outcrop DEV1. The coral buildup is covered by downlapping packstones. Unconformity DT5 and facies of the next accretional unit are also visible. C: Detail of the R6 bioherm at outcrop DEV2. The bioherm grew on a high-energy, coral rubble facies containing metre-sized blocks (marked by $B$ ) and shows a lenticular buildup crest at its top. This branching coral-dominated facies is overlain by onlapping mudstones/wackestones (OF). Thickness of the outcrop is about $15 \mathrm{~m}$. The location of the photographs is indicated on Figure 4 (Panels A, B and C).

Figure 6: Synthesis of the depositional sequence, associated sedimentary packages and processes. The depositional profile of the carbonate platform was dominantly controlled by high-frequency, moderate to low amplitude changes in the relative sea level. Increase in accommodation space triggered coral buildups. 
Figure 7: Illustration of the GPR profile P1 acquired on top of the outcrop DEV1 (location on Fig. 3). A: Photomosaic and sedimentological interpretation of the outcrop DEV1 (see Fig. 4 for details). B: Processed GPR profile P1. Plug location as indicated. Boxes indicate the close-ups used for distinction of the GPR facies (see Fig. 8).

Figure 8: GPR facies and associated sedimentary facies. Location of close-ups indicated on Figure 7 and Figure 9 as boxes.

Figure 9: Interpretation of GPR profiles based on the definition of radar facies. A: Processed GPR profiles P1 (acquired on top of outcrop DEV1) and P3 (acquired at the base of outcrop DEV1), see Figure 3 for the location of both GPR surveys. B: Interpreted GPR profiles P1 and P3. Boxes indicate close-ups used for the determination of GPR facies (see Fig. 7).

Figure 10: Synthetic sedimentological interpretation of outcrop DEV1 after the merger of GPR profiles P1 and P3. This allows major unconformities to be extended and the base of the coral bioherms to be identified. 
Figure 1

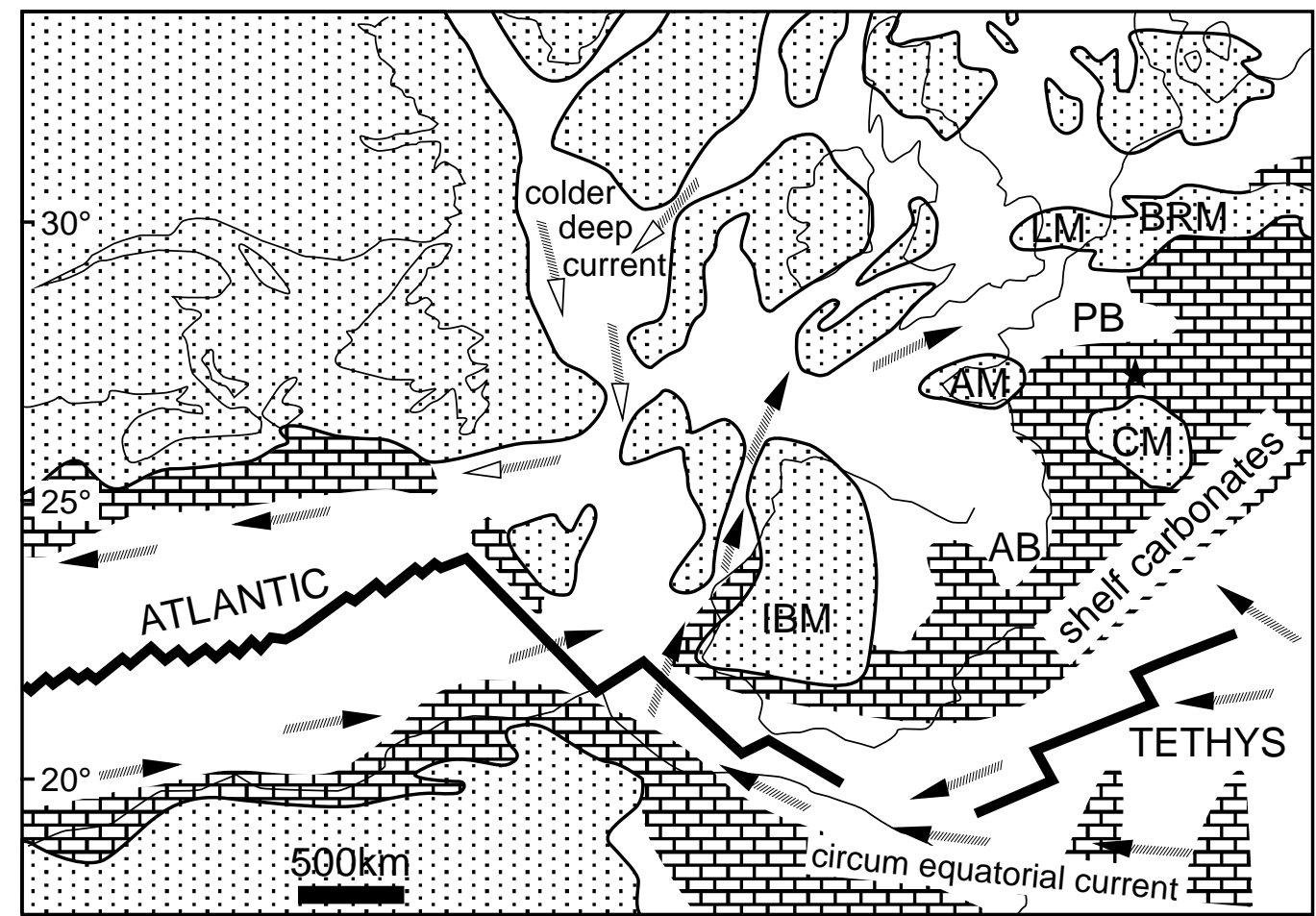

दि land

shelf carbonates

- oceanic currents
AB: Armoricain Basin

PB: Paris Basin

AM: Armorican Massif

BRM: Brabant Massif
CM: Central Massif IBM: Iberian Massif LM: London Massif $\star$ : studied area 
Figure 2
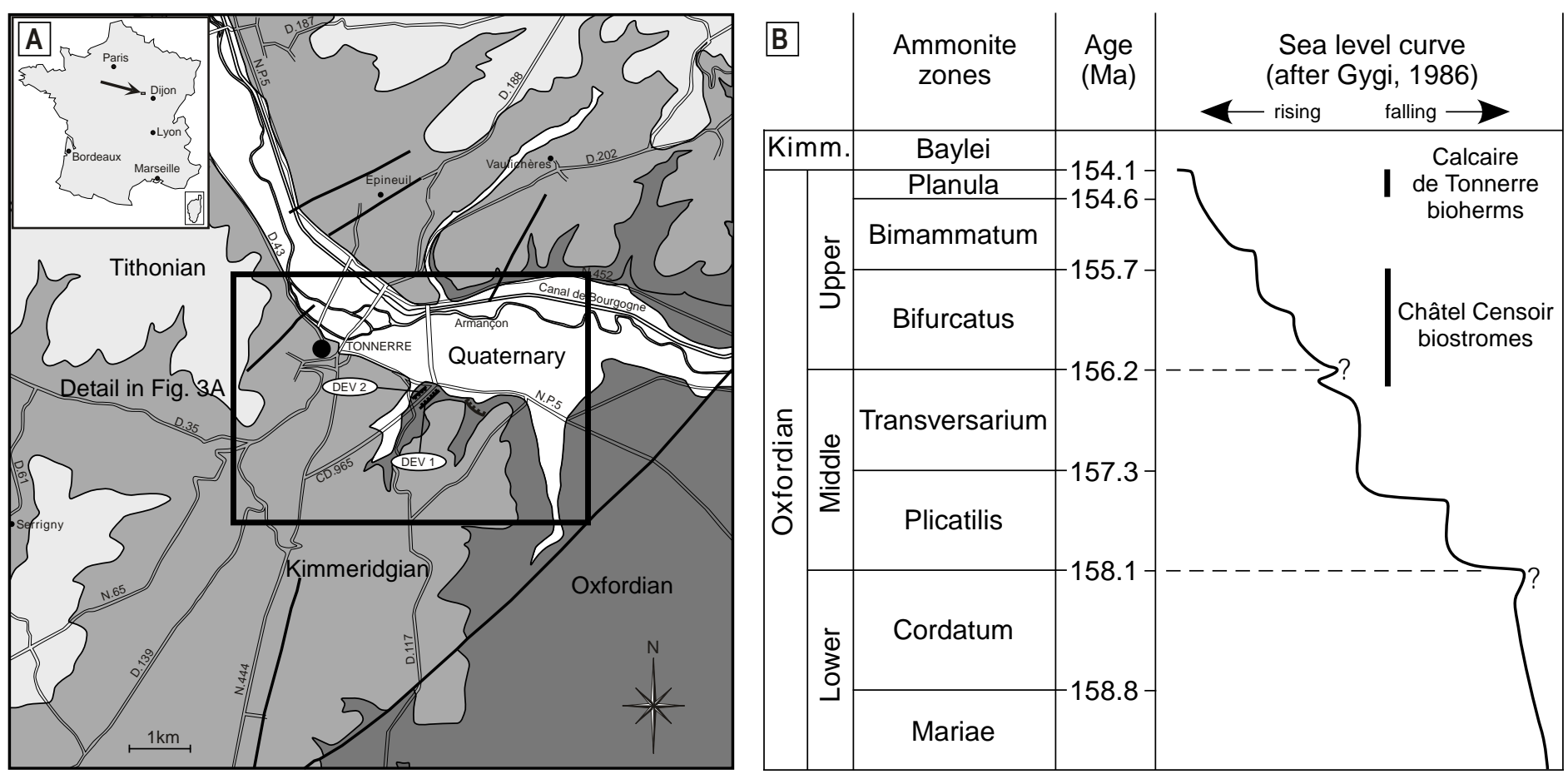
Figure 3
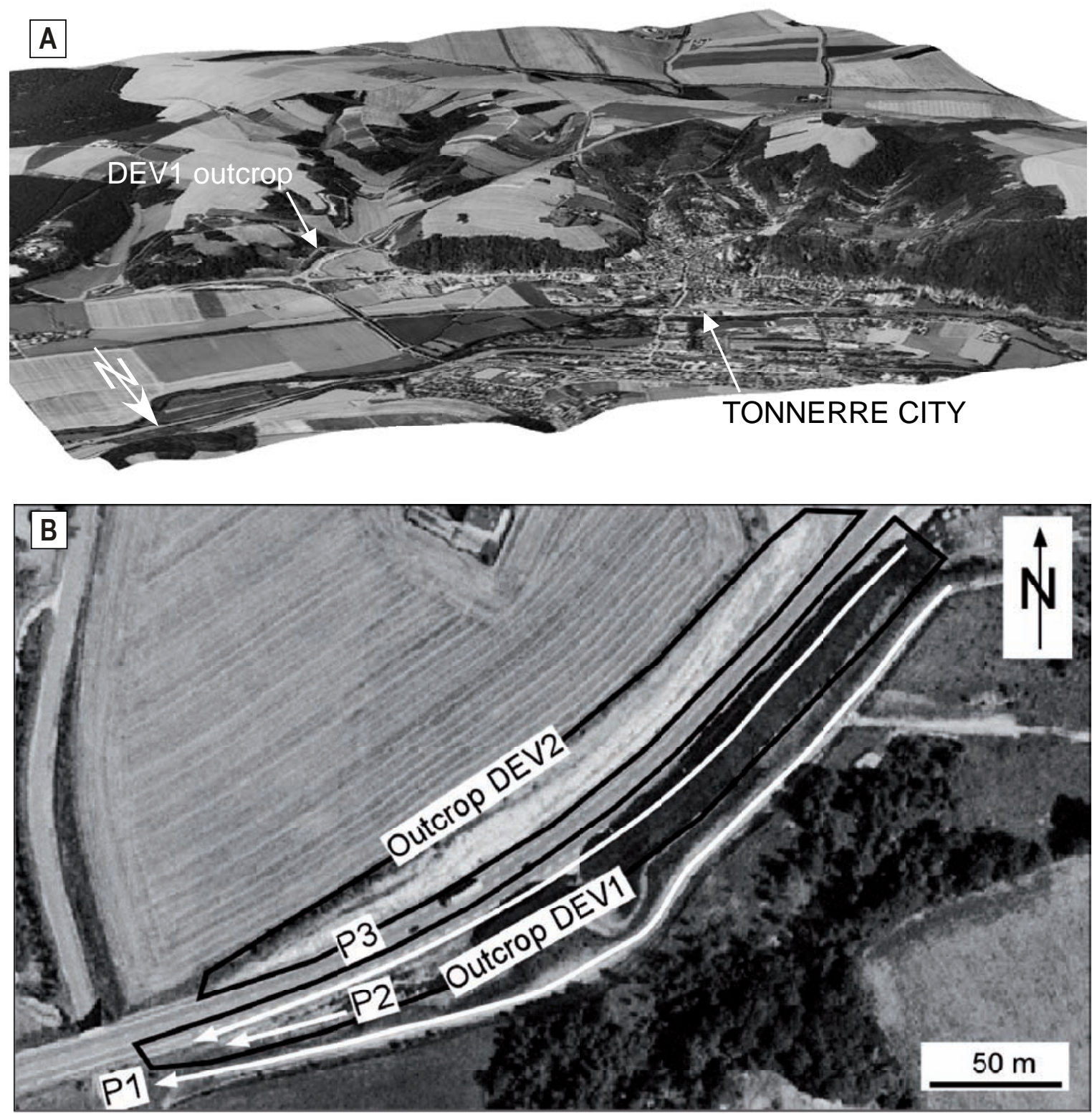

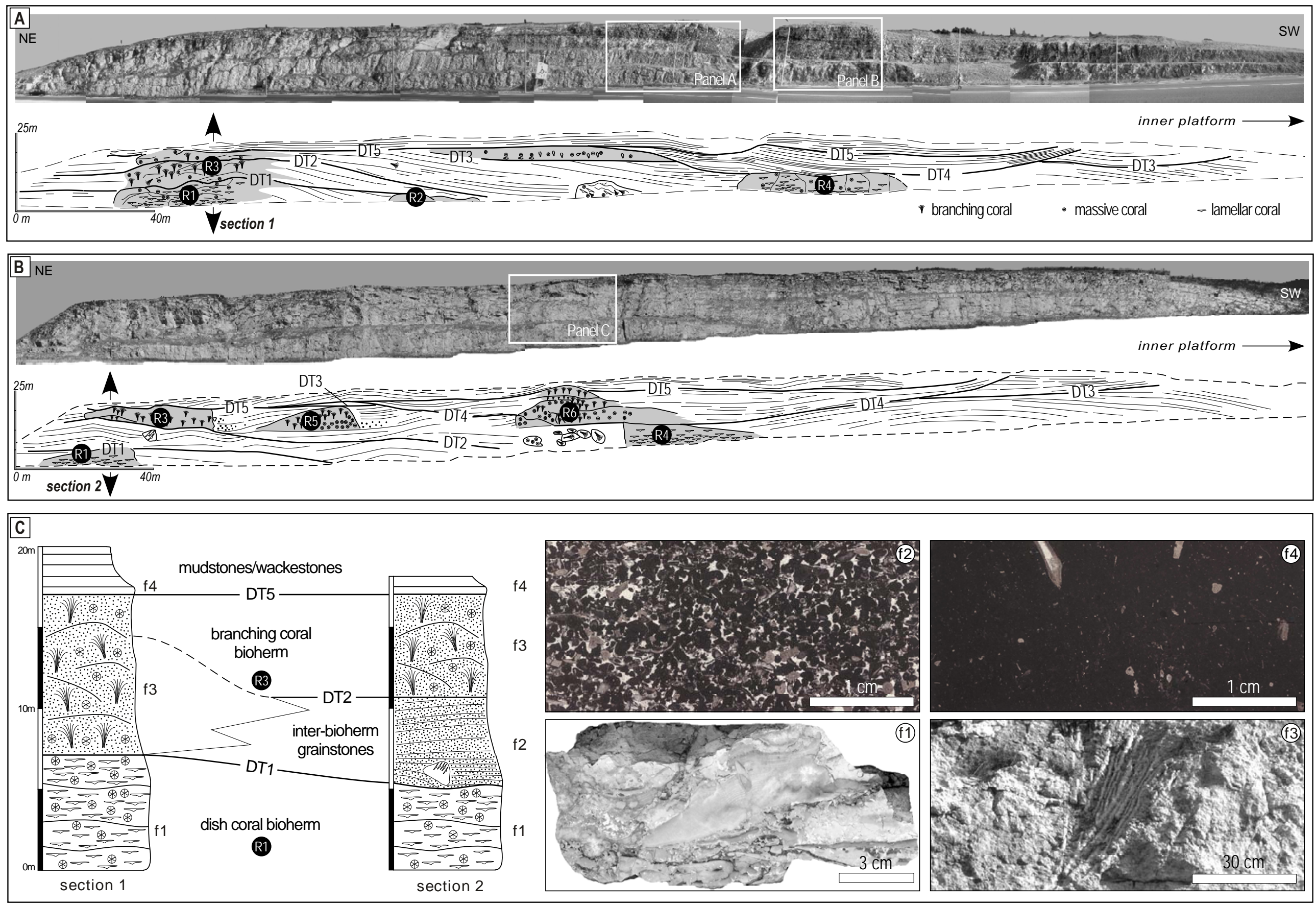
Figure 5
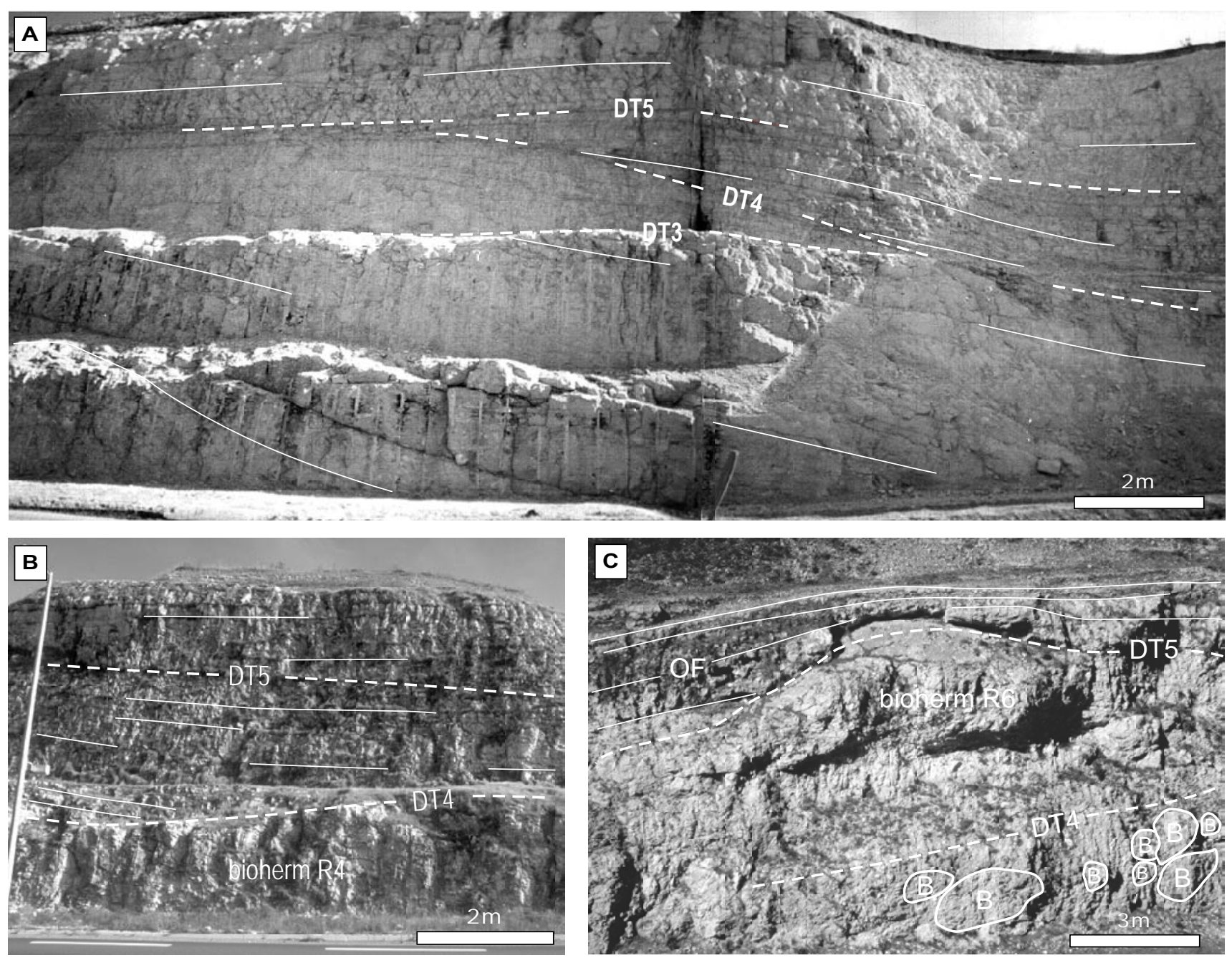


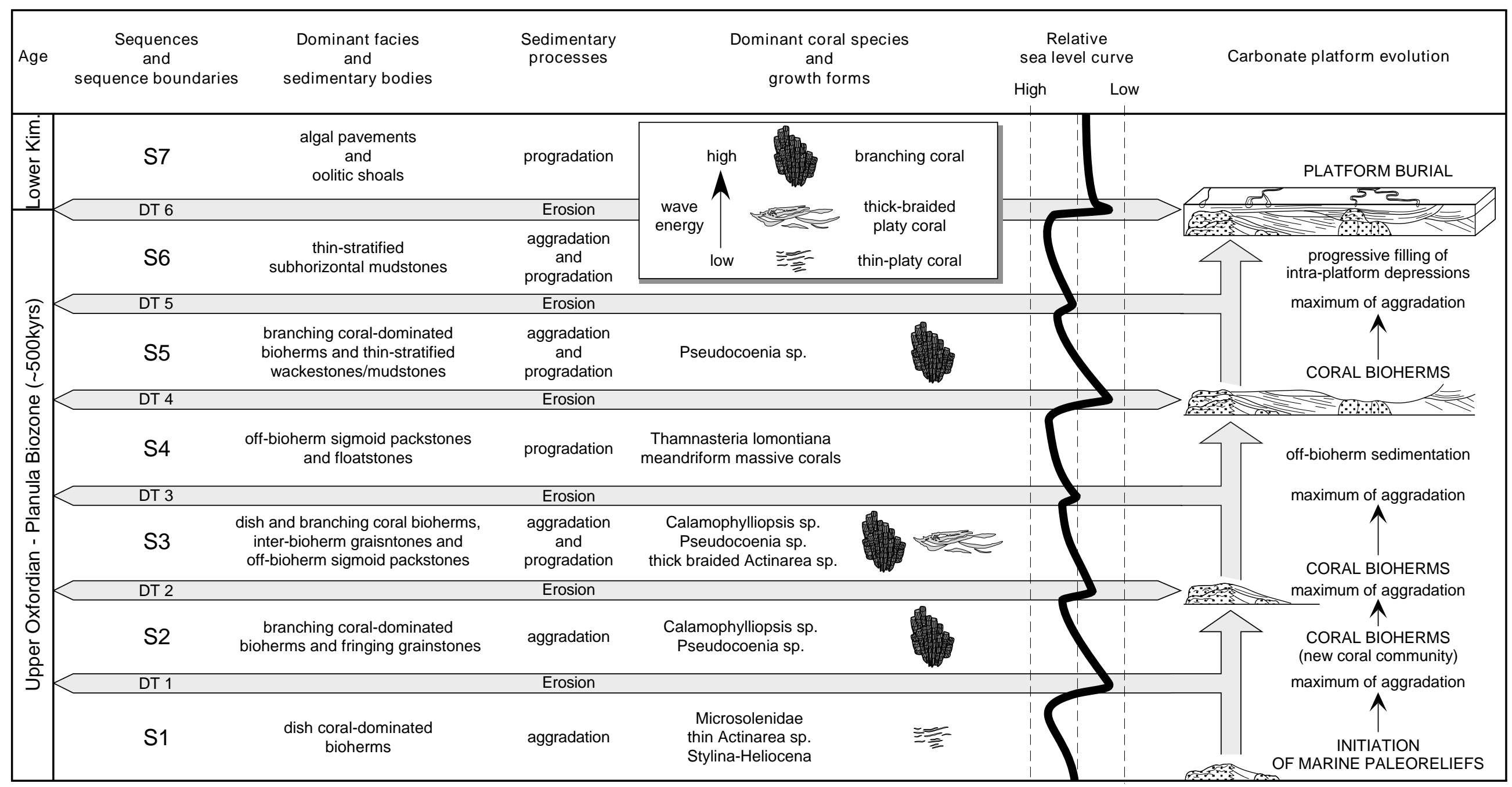




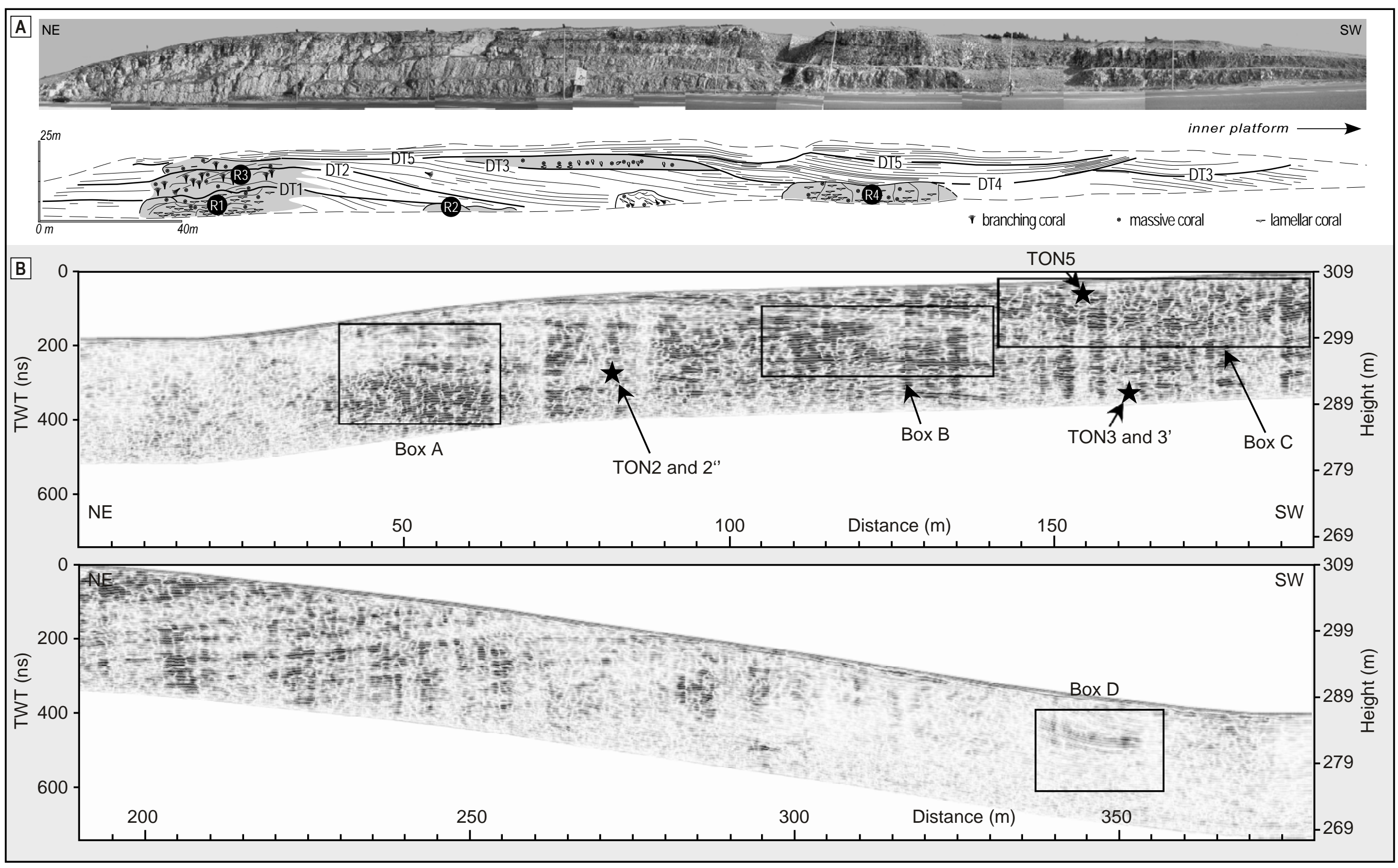


Coral bioherms

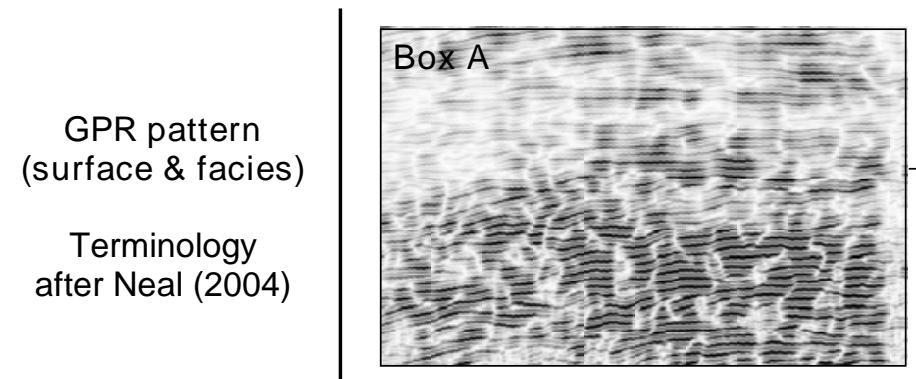

b) Continuous subparallel reflexion a) Strong, chaotic, and discontinuous reflectors

Sedimentary facies (surface \& facies)

Terminology after Neal (2004)

b)

a)

a) b) bioclastic packstone/grainstone a) corals with peloidal/bioclastic packstone/grainstone matrix

$10 \mathrm{~m}$

Medium-scale channel-fill sequence

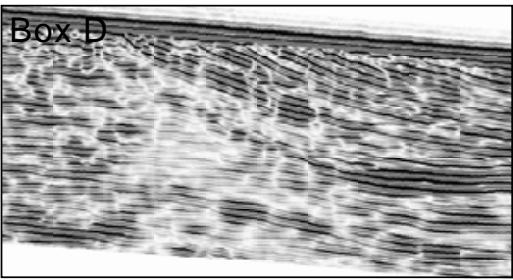

Continuous, concave reflections; Erosional truncation
Prograding units

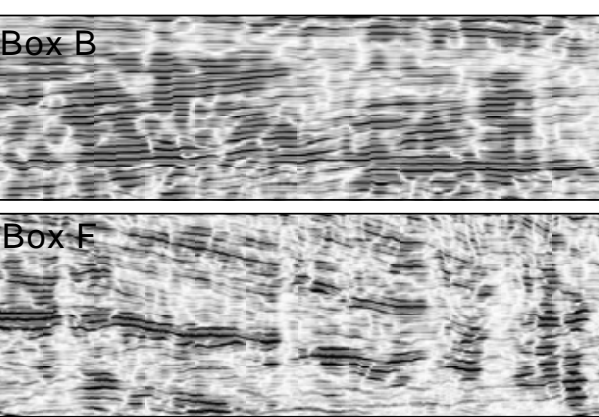

Continuous reflections, sigmoid to oblique shape, tangential basal contact, toplapping upper contact
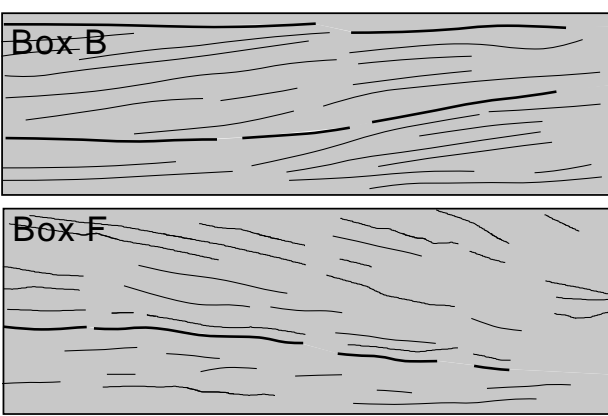

bioclastic packstone/grainstone

$$
10 \mathrm{~m}
$$

Large-scale channel-fill sequence
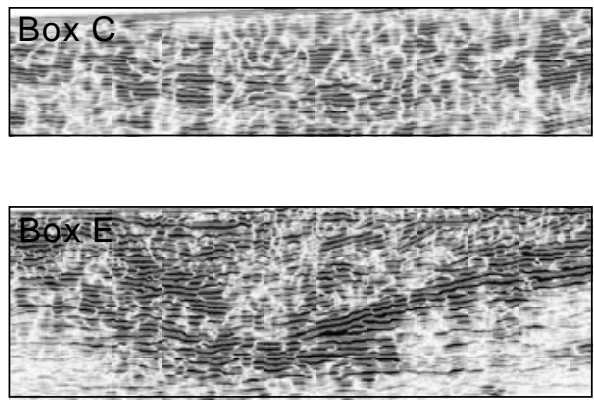

Moderately continuous, concave reflections, erosional truncation
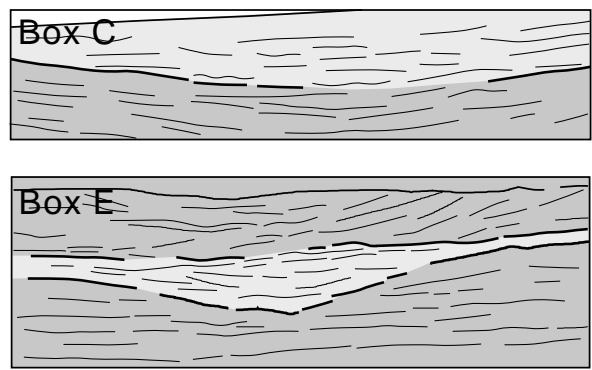

wackestone/mudstone

$10 \mathrm{~m}$ 


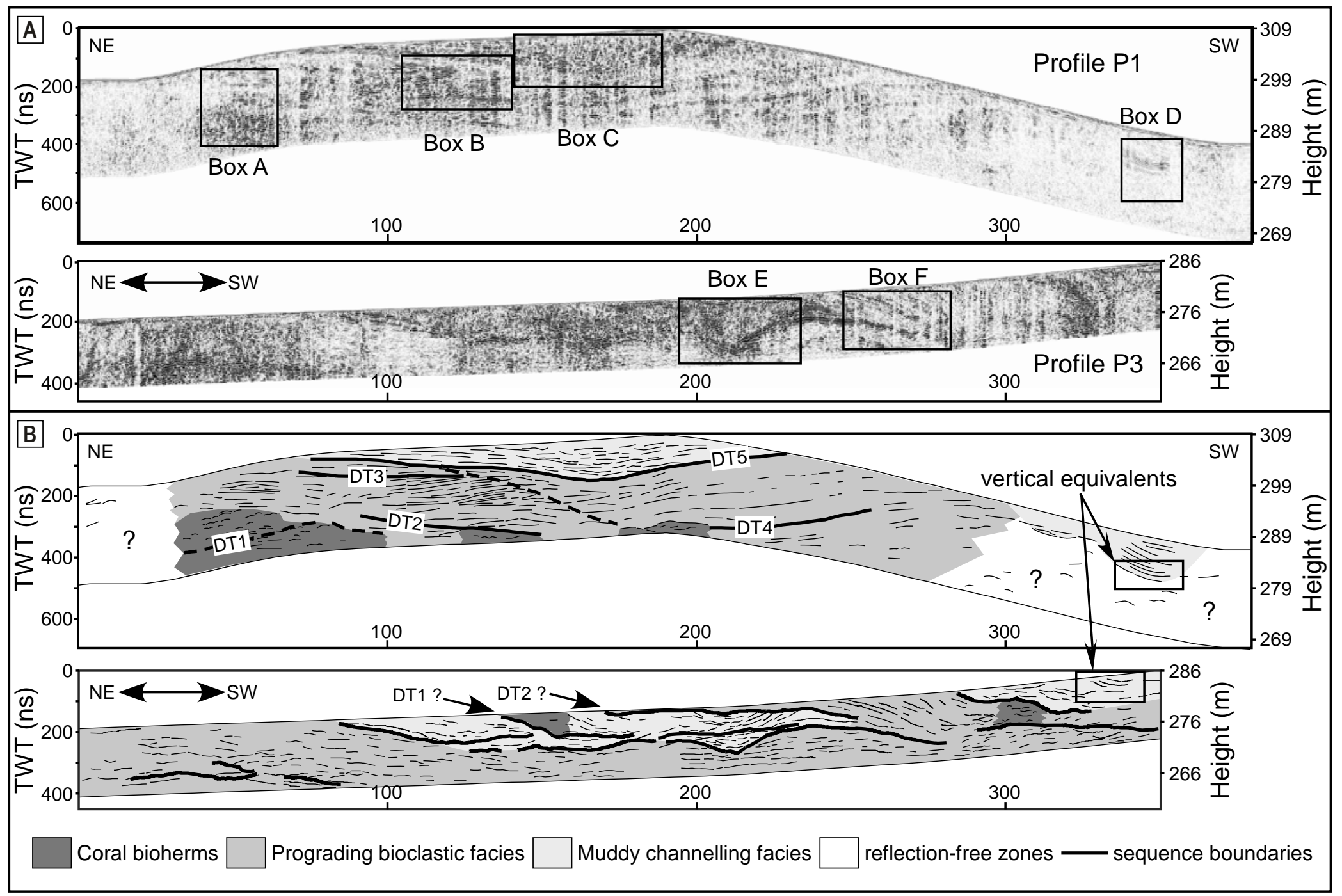




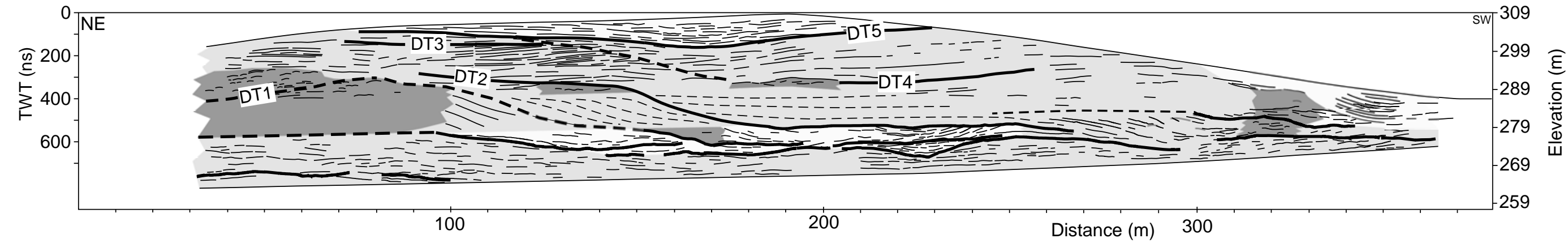

$\square$ Coral bioherms $\square$ Prograding bioclastic facies $\square$ Muddy channeling facies 